\title{
Parks, people, and change: the importance of multistakeholder engagement in adaptation planning for conserved areas
}

\author{
Corrine N. Knapp ${ }^{1}, \underline{\text { F. Stuart Chapin III }}^{2}$, Gary P. Kofinas $^{2}$, Nancy Fresco $^{3}$, Courtney Carothers $^{4}$ and Amy Craver $^{5}$
}

\begin{abstract}
Climate change challenges the traditional goals and conservation strategies of protected areas, necessitating adaptation to changing conditions. Denali National Park and Preserve (Denali) in south central Alaska, USA, is a vast landscape that is responding to climate change in ways that will impact both ecological resources and local communities. Local observations help to inform understanding of climate change and adaptation planning, but whose knowledge is most important to consider? For this project we interviewed long-term Denali staff, scientists, subsistence community members, bus drivers, and business owners to assess what types of observations each can contribute, how climate change is impacting each, and what they think the National Park Service should do to adapt. The project shows that each type of long-term observer has different types of observations, but that those who depend more directly on natural resources for their livelihoods have more and different observations than those who do not. These findings suggest that engaging multiple groups of stakeholders who interact with the park in distinct ways adds substantially to the information provided by Denali staff and scientists and offers a broader foundation for adaptation planning. It also suggests that traditional protected area paradigms that fail to learn from and foster appropriate engagement of people may be maladaptive in the context of climate change.
\end{abstract}

Key Words: Conservation; climate change; local knowledge; National Park; resilience; social-ecological systems

\section{INTRODUCTION}

Climate change challenges the core assumptions and traditional strategies of protected areas management around the globe (Hagerman et al. 2010). Global impacts to conserved areas have been documented, from melting glaciers in Sagarmatha National Park to coral bleaching in the Great Barrier Reef in Australia (UNESCO World Heritage Centre 2007). Given the staggering projections for loss of biodiversity due to climate change (Thomas et. al 2004), there have been increased calls for more inclusive planning processes and coordination between conserved areas and surrounding communities (Heller and Zavaleta 2009). Although change is impacting conserved areas in all regions, the changes are magnified at high latitudes (Serreze et al. 2000). This paper presents a case study of multistakeholder observations of climate change impacts and suggestions for adaptation in Denali National Park and Preserve (henceforth Denali or the Park) in Alaska, USA.

In the United States, the National Park Service(NPS) is the agency tasked with protecting iconic natural resources, including their functional, aesthetic, and cultural values. The NPS has received direction to integrate climate change into park planning and has responded both nationally (NPS 2010a) and within Alaska (NPS 2010b). The NPS Climate Action Plan states, "Partners are essential to acquire new knowledge about climate change and its impacts, raise awareness regarding those impacts to places people care about, and evaluate and implement strategies and actions that require cooperation outside park boundaries (NPS 2012:18)." Despite this recognition, there is little direction about who to include in these efforts. In this paper we report the results of interviews with different groups of long-term Denali region residents to understand their observations of climate change, how it impacts them, and their suggestions about how Denali could adapt. Our objective is to clarify who is important to engage in adaptation planning for conserved areas and the regions that surround them.
National Parks have historically relied on the knowledge and opinions of experts, including conservation biologists, plant ecologists, and landscape planners, to draw their boundaries, understand resources, and manage landscapes. Local residents were historically not included in these processes and often removed from these landscapes to establish natural areas devoid of human influence (Dowie 2009). In Denali, knowledge of Park resources and change is primarily accomplished through monitoring. Managers have implemented an ambitious monitoring protocol to systematically track change (Roland et al. 2013), but it is expensive and limited to preidentified variables.

Adaptation has traditionally been a local process requiring local understanding. Global climate change suggests the need for largescale adaptation, which corresponds with the development of institutions that manage large spatial units and centralized knowledge structures. Institutional structures and regulations can create barriers to adaptive responses to environmental change (Benson and Garmestani 2011). NPS staff have recognized these barriers and expressed concern that adaption is discussed more often than implemented (Jantarasami et al. 2010). General suggestions about climate adaptation planning have emerged (e.g., CEQ 2011, Peterson et al. 2011), but processes for local-scale adaptation are less clear. Adaptation processes often focus on those with formal training or official positions, which may exclude some individuals with long-term observations (Ogden and Innes 2009). People in official roles or with formal training commonly make fundamental decisions about adaptation, with local stakeholders merely responding to predefined options (Treby and Clark 2004). As adaptation planning increases, it is critical to consider whether and why to engage residents with long-term observations.

The value of local knowledge and beliefs for informing climate change adaptation is increasingly recognized (Vogel et al. 2007). Local knowledge can contribute accurate observations of change (Krupnik and Jolly 2002), increased commitment to implementing

${ }^{1}$ Department of Environment and Sustainability, Western State Colorado University, ${ }^{2}$ Institute of Arctic Biology, University of Alaska Fairbanks, USA, ${ }^{3}$ Scenarios Network for Alaska and Arctic Planning, University of Alaska Fairbanks, USA, ${ }^{4}$ School of Fisheries and Ocean Sciences, University of Alaska Fairbanks, USA, ${ }^{5}$ Denali National Park and Preserve 
adaptation strategies (Tompkins et al. 2008), and understanding of interactions between adaptation strategies developed at different levels (Adger et al. 2005). Local residents, however, may differ from scientists in their beliefs about causes of observed changes (Byg and Salick 2009). Knowledge generation is a dynamic and integrative process, and dichotomizing definitions of local or scientific knowledge are simplistic (Agrawal 1995). Many of the participants in this study have access to park science through publications, trainings, and seminars. This dialectic relationship between what we learn and what we see is an unavoidable component of human perception (Weber 2010). This project compares the observations of different types of long-term residents to understand whose knowledge is important to engage in adaptation planning.

\section{Description of study area}

Denali was established in south central Alaska in 1917 with 2 million acres and was expanded to 6 million acres in 1980 with the passing of the Alaska National Interest Land Conservation Act (ANILCA). Under ANILCA, many of the lands added to Alaskan National Parks were designated as Preserves, which allow for certain types of use depending on the specific enabling legislation (Government of USA 1980). Seasonally nomadic Athabascan people were the earliest residents of the Denali region, settling in permanent villages only within the past century (Collins 2004). Nikolai, on the Upper Kuskoquim, is a primarily Athabascan community, whereas Cantwell is a quarter Athabascan. The primarily non-native communities, McKinley Village, Healy, and Talkeetna, are linked to tourism associated with the Park or economic development of the region during the oil boom. All of the communities rely on resources adjacent to and shared with Denali for their livelihoods. The year-round population of the communities surrounding the Park is less than 2000 compared with annual visitation of over 400,000 visitors.

Our interviews took place in the Denali region (Fig. 1), which includes the Park, Preserve, and surrounding communities. Interviews took place in Cantwell (residents [r]: 207), McKinley Village (r: 188), Healy (r: 1084), Lake Minchumina (r: 12), and Nikolai (r: 94), as well as with park employees (State of Alaska 2013). Cantwell, McKinley Village, and Healy are all located along the Fairbanks-Anchorage road system. Residents in these communities participate in some subsistence activities, but primarily make their living through employment with the Park, schools, tourism, or mining. Lake Minchumina and Nikolai are off the road system, and most households participate in subsistence activities, work for local or tribal governments, or fight fires. The Park is closed to subsistence activities, but some residents utilize areas in the 1980 Preserve additions for subsistence activities. The primary subsistence foods for these communities are salmon, moose, berries, and waterfowl (ADFG 2013). Almost all subsistence participants utilize each of these resources, although harvest levels may vary because of income, available equipment, harvest and access restrictions, physical ability, and need.

\section{METHODS}

Our criteria for selecting community and Denali-employee participants were that they: (1) were either full time or seasonal residents for at least nine years, (2) spend or spent more than 30 days a year on the land, and (3) were recommended by other community members. We asked Denali employees, Denali
Subsistence Resource Commission members, and tribal council members to recommend knowledgeable residents who met these criteria. We used snowball sampling to ask preliminary participants for additional recommendations (Denzin and Lincoln 2005). We prioritized individuals based on the number of recommendations, while making sure we had adequate representation of each community and stakeholder group. In Nikolai, a community liaison was hired to help coordinate interviews with community members. NPS and researchers cohosted preproject community meetings in the two off-road communities to introduce our research, obtain permission, and collect feedback about the methods and utility of the research. Prior to each interview, researchers provided information about the project and then acquired oral consent from each participant (UAF IRB\# 220265-3).

Fig. 1. Communities surrounding Denali that participated in project interviews.

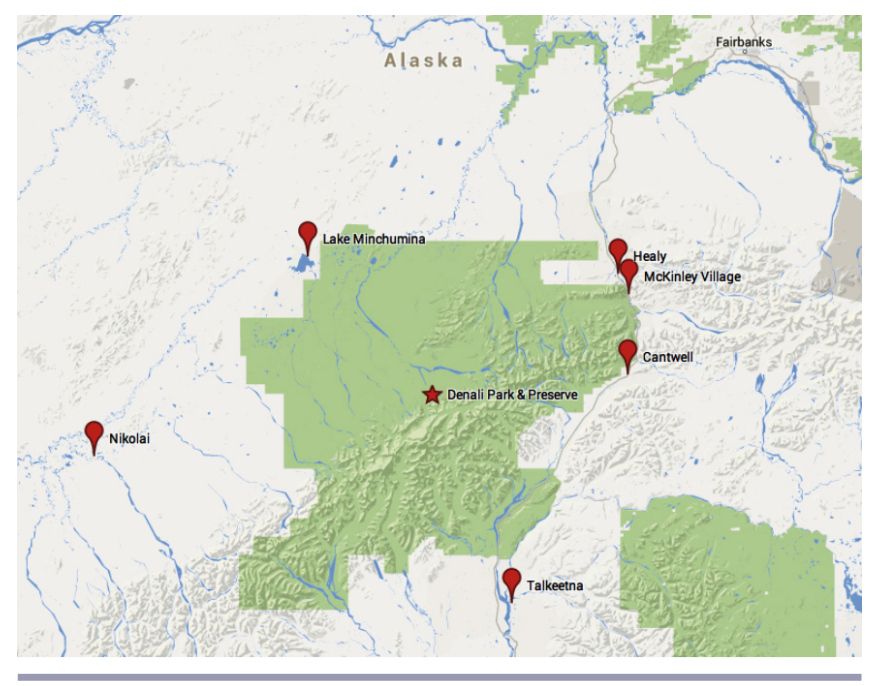

Semistructured interviews (Denzin and Lincoln 2005) included topics such as personal history, perceptions of change, climate change impacts, and potential adaptations. Participants were asked to highlight obvious changes first and then were prompted with a list of potential change areas (e.g., vegetation, wildlife, weather). Results are given in percentage of participants who observed and mentioned each change. Participants shared different observations, but there was little disagreement between observations. The interview process and topic guide were pretested prior to collecting project data. We conducted 65 interviews with 83 individuals (Appendix 1). There were no differences in the types or number of observations that arose in multiperson family interviews. Our primary focus was on subsistence community members (39), but we also interviewed tour bus drivers (8), NPS employees/scientists (18; primarily wildlife biologists and ecologists), and business owners (18; e.g., pilots, artists, tourist businesses). The majority of participants were male $(63 \%)$. We completed interviews between 2011 and 2012. Interviews lasted between one and three hours, and were audio-recorded and later transcribed.

We used NVIVO, a qualitative data analysis program, to code each interview transcript (see Appendix 2 for more detail). We were then able to run quantitative reports as well as to collect the 
qualitative text referring to each theme. Finally, we wanted to understand how long-term observations compared with scientific findings from this region. We searched for peer-reviewed articles in Web of Science, reviewed and summarized the findings (Appendix 3). We found no scientific evidence that contradicted stakeholder observations.

\section{RESULTS}

Types of experience and land use

All of the participants had long-term observations of the Denali region, but varied their interactions with the natural environment. Subsistence users had the most consistent interaction with the natural environment primarily through hunting, trapping, fishing, and gathering wood. They often travel long distances by boat, snowmobile, and dogsled to access resources throughout the year. Other long-term residents were primarily outdoors during the summer and fall driving buses (bus drivers), monitoring (scientists and NPS staff), hunting (NPS staff and business owners), and recreating (all of the above). Subsistence users commonly relied on Preserve areas, while other long-term residents relied on the Park (employment or ownership of Parkrelated businesses).

\section{Observations of change}

\section{Climate change}

Nearly all (98\%) participants reported climate change observations. There was large variation in the number and types of observations from several to dozens. Many participants specified the timeframe over which they had made each observation, e.g., within the last 20 years or since employment at the Park began. On average, participants have been residents for 42 years (y). Subsistence (49y) and business owners (43y) were the longest-term residents, followed by park staff/scientists (32y) and bus drivers (29y). Participants also separated short-term variations, such as drier or wetter years, from long-term trends, such as lower overall snowfalls. Most participants used their earliest experience in the Denali region as their baseline for observing change, so they differed in the baseline they used to assess change. Although participants described observations of change, they often expressed caution about attributing those changes to climate change alone.

Participants' observations directly related to climate change fell into three primary categories: hydrology, vegetation, and weather. Some observations were mentioned frequently, e.g., temperature increase $(71 \%)$, faster vegetation growth $(59 \%)$, less snow $(49 \%)$, drying ponds $(49 \%)$, whereas others were less frequently mentioned, e.g., rising firn line $(9 \%)$, increased erosion $(9 \%)$, or had more varied responses, e.g., amount of wind or river level. Subsistence users described phenomena that impacted travel including later freeze up (28\%), gentler break up (21\%), lowered river levels $(31 \%)$, and channelized rivers $(10 \%)$. Although less frequently mentioned, participants also addressed increased thunderstorms $(14 \%)$, increased winter rain $(19 \%)$, and later arrival of snow (14\%). Many of these observations are consistent with current scientific literature (Appendix 3), although some observations had not been documented previously.

The nature of participant interactions and experiences with the natural world influenced their observations and interpretations
(Fig. 2). Subsistence participants travel to hunt, fish, gather, and trap, so they made more observations about changes that impacted ease of travel across the landscape. Bus drivers, in comparison, described phenomena observable from the Park road. Business owners often observed changes at lower elevations, such as less overall snow and increased vegetation growth. These observations varied based on the type of business owners, with pilots describing landscape changes observed from planes, e.g., glacial retreat or vegetation, guides expressing changes on $\mathrm{Mt}$ McKinley, and front-country business owners primarily expressing changes along the Park road or on adjacent lands. Both Denali employees and scientists affiliated with other institutions described fewer observations of change. Their most common observations were the tree line moving upward and increased vegetation growth.

Fig. 2. Percentage of each participant type who mentioned each climate change observation. See Appendix 3 for the full list of observations. NPS = National Park Service.

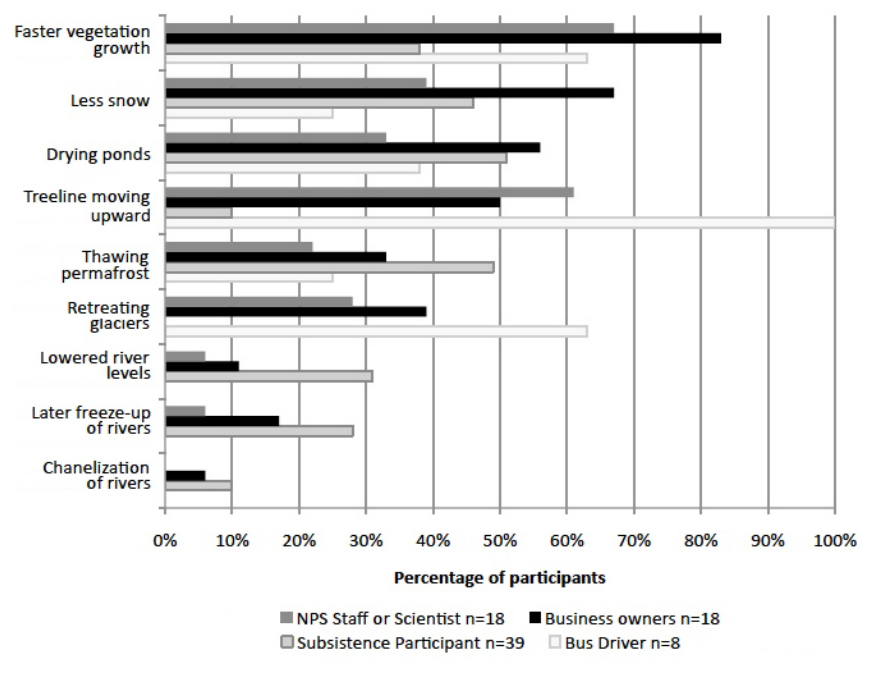

Other changes

Participants described other changes that were either unrelated, partially related, or only potentially related to climate change (Appendix 4). Conversations often weaved environmental and social drivers of change together in a seamless manner, with rapid transitions between the two. This pattern of shifting from environmental to social drivers was more common in subsistence users, bus drivers, and business owners. The most commonly described changes were related to wildlife (92\%) and to the Park experience $(47 \%)$. Participants described changes in the locations where they observed wildlife. For instance, subsistence hunters described a decrease in moose along rivers. Changes to the park experience included more people in the backcountry, new infrastructure, and increased traffic on the roads. Other changes included population size and cohesiveness of surrounding communities $(41 \%)$ and new technologies, e.g., freezers and snow machines $(40 \%)$. Subsistence community members were concerned about the next generations' lowered interest in tradition $(36 \%)$. Bus drivers $(88 \%)$ and long-time local residents $(56 \%)$ were concerned about increased pressure for access to the 
Park. These changes were described in tandem with potential climate changes, as part of the lived experience of long-term community members.

\section{Impacts on people's lives}

Many participants identified climate change impacts (87\%), and there was greater variation in the types of impacts mentioned (Appendix 5) than in observations of change (Appendix $3 \& 4$ ). We asked participants to share how changing climate had impacted them, either positively or negatively. Consistent impacts included: shift in the distribution of animals (36\%), changes to wildlife viewing $(28 \%)$, and changes in timing of river access $(22 \%)$. Impacts were primarily negative, although some positive impacts were mentioned (e.g., increased gardening season, easier to warm houses). This result matches previous research that documents more negative than positive implications of climate change (Berkes and Jolly 2001). Impacts varied by stakeholder group (Appendix 5), with subsistence participants talking more frequently about impacts from shifts in distribution of animals (49\%), restricted access (rivers; 36\%, snow: $26 \%$ ), and hunting success (26\%). Park employees described changes they had made to Park monitoring $(22 \%)$, maintenance due to increased brush along roads $(17 \%)$, infrastructure impacts $(17 \%)$, and shifts in the distribution of animals $(17 \%)$. Bus drivers focused on wildlife viewing opportunities for Park visitors (75\%) as well as changes in climate-change communication $(38 \%)$. Business owners described changes in the distribution of animals $(44 \%)$ and infrastructure impacts $(17 \%)$. Subsistence residents made uncommon observations including impacts on gathering berries and wood, trapping, and water quality ( $3 \%$ each). Climate change impacts are also amplified or mitigated by their interactions with nonclimate-change-related drivers. For instance, warmer weather has lengthened the tourist season, which could increase access demands. On the other hand, the impact of a warmer fall on storing meat is mitigated by increased use of freezers.

\section{Potential adaptations}

We asked participants to provide advice about how Denali should adapt to observed changes. Their suggestions stem from climate change observations as well as other political, social, and economic drivers of change. Participants could list as many adaptation options as they wanted to, or none. A large percentage $(45 \%)$ of the participants did not mention adaptation actions. This group explained that they either did not know what the Park should do $(10 \%)$ or did not think their thoughts would be valuable to the Park (35\%).

Participants provided five primary suggestions (Fig. 3), including education $(25 \%)$, maintaining a quality experience $(22 \%)$, maintaining subsistence (22\%), changing Park identity (17\%), and continuing current monitoring (12\%). Increased education about climate change was seen as an important strategy because National Parks have concrete examples of climate change that could motivate the public to act. This suggestion arose from all stakeholder groups. Individuals who suggested maintaining the quality of the Park experience tied this suggestion to increased pressure for Park access, changes to Park philosophy that valued infrastructure and revenue over natural resources, and changes in wildlife due to changes in vegetation and hydrology. These participants expressed how caution should be used to protect resources in the midst of multiple drivers of change. Bus drivers
Fig. 3. Percentage of each participant type who mentioned each climate change adaptation strategy. NPS = National Park Service.

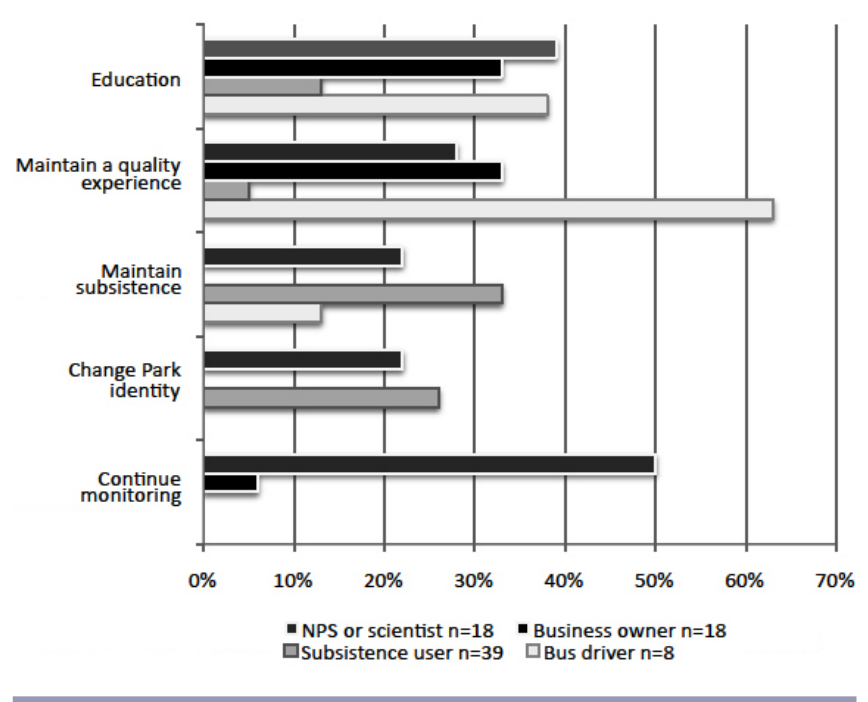

were most likely to mention the quality of the Park experience $(63 \%)$, but business owners (33\%) and Denali employees $(28 \%)$ also mentioned it.

Many subsistence users (33\%) and some NPS employees $(22 \%)$ and bus drivers $(12 \%)$ stated that it was important to protect the opportunity and practice of subsistence in the Denali region as well as the Preserve. This strategy was connected both to climate change impacts and other drivers of change (outmigration, technology, economics). Participants suggested several ways subsistence could be supported within a context of climate change including: valuing the observations of subsistence users, allowing regulatory flexibility for hunting and trapping, helping support income generation, and thinking creatively about how subsistence will be passed on to the next generation. Specific suggestions for changes in Park management included: shifts in hunting regulations based on yearly weather, reestablishment of traditional practices such as sheep hunts, and changes to regulations to allow younger family members to hunt for elders.

Subsistence users (26\%) and Park employees (22\%) described the need to adjust the Park's identity to reflect a changing environment. Subsistence users suggested the Park should adapt in the same way that subsistence users adjust to changing resources. They suggested adaptation options that maintained basic services of the Park (education, tourism, subsistence) without trying to preserve the current status of natural resources within the park. Park employees also described a need to shift their focus as resources within Park boundaries shift. These suggestions match with resilience theory, which suggests that resisting change may make the overall system less resilient (Chapin et al. 2009). Finally, Park employees often (50\%) talked about the need to continue monitoring to understand change. Many of these individuals talked about how change can be challenging to see and how accurate and systematic monitoring can help to perceive changes that are gradual or contain a lot of variation. 


\section{Suggestions for more effective integration}

We asked participants to discuss how local observations and knowledge could be more effectively integrated into adaptation decision making. Participants agreed that local observations were an important resource, but felt that current information-sharing structures, e.g., public comment periods, were a formality and did not influence decision making. Although they described a need for Park employees to listen, they had few suggestions about what a new structure of knowledge sharing might look like.

\section{DISCUSSION}

\section{Knowledge for adaptation}

\section{Novel observations}

Prior studies of local observations of climate change focus primarily on a single type of local resident (e.g., Krupnik and Jolly 2002), and most do not compare the observations of different types of long-term residents to see what each contributes. Because protected area decision making is usually informed by science and managed by bureaucrats (Caughley and Gunn 1996), it is important to understand how observations of Park staff and scientists differ from those of other long-term residents. We found that long-term residents who interact with the landscape on a regular basis may have more and different types of observations of change than long-term residents who are in official roles (Park employees) or have formal training (scientists). Our study found that subsistence users and business owners perceived changes on the landscape that were rarely mentioned by Park staff or scientists, including changes to the timing of freeze-up, lowered river levels, and increased thunderstorms and wind. Their practical and daily interaction with the environment provide insights that would otherwise be unrecorded. Less common observations were typically associated with phenomena that would only be observed by specific people (pilots: firn line; trappers: steep banks). In contrast, Park staff and scientists were more likely to share observations that corresponded to scientific research. This may reflect hesitance by staff and scientists to report personal observations that are unsupported by data, but it may also reflect greater familiarity of long-term local residents who rely and interact with the natural environment year-round. This suggests that a diverse group of observers can provide a broader range of climate-change observations and that decision-making processes should be created that engage and incorporate the observations of long-term local residents who utilize resources in conserved areas.

\section{Awareness of interactions}

It has been suggested that local residents can provide insight about how climate change interacts with other stressors (Moerlein and Carothers 2012). This project expands this insight by suggesting that different types of long-term residents are aware of different interactions. Most project participants described how climate change interacts with simultaneous social, political, and economic changes. Changes in wildlife were a concern to all long-term residents, while concern about other changes varied by group (Appendix 5). For instance, bus drivers focused on changes in the Park experience and philosophy, while subsistence residents talked about changes to their community and technology. The drivers of change that communities discussed ranged from the local (changes in wildlife) to regional (air quality) to global (technology). Many of these drivers have cross-scale impacts, e.g., economics leading to outmigration and change in community structure, technology changing local practices. This project demonstrates that different types of residents identify different cross-scale interactions, which are important for understanding how to adapt effectively to climate change (Adger et al. 2005). If planners and managers proceed with adaptation strategies that ignore this larger context, they are bound to be ineffective or have unintended consequences (Turner et al. 2003).

\section{More equitable outcomes}

Subsistence users rely on Preserve areas for their livelihood, whereas other long-term residents rely more on Park areas. Changes to policy within Denali in response to climate change could have differential impacts on livelihoods. This project demonstrated how stakeholders have different observations of climate change, experienced distinct impacts, and suggested varied ways to adapt. If Park employees make adaptation decisions without engaging long-term residents, they may fail to understand how change is occurring or how it is impacting local residents. Adaptation will happen at all levels of organization as both conscious strategies and unconscious adjustments to changes in resources. These adaptations can be synergistic or can work at cross-purposes (Adger et al. 2005). If individual trappers, subsistence participants, Park employees, and Park management better understand the observations and adaptations of one another, broadly compatible adaptation is more likely to occur.

\section{Increase system resilience}

As conserved areas become more challenging to preserve in their current state, a focus on increasing resilience of systems may be a more viable and useful goal (Folke 2006). This project demonstrates how people who interact with the system on a regular basis can increase its resilience by providing qualities such as memory, diversity, redundancy, and feedbacks, all of which have been associated with higher levels of resilience (Chapin et al. 2009). Participants provided memory of how Denali has changed over time. Although visitors perceive Denali as a wildliferich landscape, local residents described changes in wildlife populations and distribution. Participants provided diversity through observations made in different locations and in different manners. Residents provided redundancy by making observations in different places, with different tools, and for different reasons. Local knowledge provided relatively fast and immediate information about the state and changes in a system that can inform the design of scientific studies that generally detect changes over longer time horizons. Perceptions of climate change are critical to understand, because people make decisions based on what they perceive, and these decisions can influence the ecosystems they rely upon (Gearheard et al. 2010). Understanding how people are adjusting to the changes they perceive may provide insights about the indirect impacts and feedbacks of human responses to climate change.

\section{The value of people in nature}

There are multiple international models regarding the role of local people with protected areas, ranging from Biosphere Reserves, where people live in parks and their activities and use are part of what the park is intended to protect, to African game parks, where residents have been removed to provide an opportunity for visitors to interact with wildlife without human interference (Berkes et al. 2009). Denali allows some level of human use in the Park 
(recreation, science, management activities) and in the Preserve (subsistence). Although some level of use continues, removal of residents has been a part of the history of National Parks (Dowie 2009). Prior research has shown that protected areas are impacted by surrounding landscapes (Shafer 2012), and that parks can no longer function as islands separated from the larger context, either in terms of biological or social interconnections (Hagerman et al. 2010).

The use of Preserve areas is a historic legacy of negotiations over expansion of the Park, but this study suggests that there is value in having people on the land. By interacting in diverse ways with natural systems, local people make novel observations of species (Low et al. 2009), provide insight into complex interactions (Beall and Zeoli 2008), and develop locally adapted conservation practices (Berkes et al. 2000). People whose livelihoods rely on particular climate, weather patterns, and resources are more likely to be aware of subtle shifts to these patterns and successfully adapt to them. This project expands these findings by suggesting that maintaining diverse uses of protected areas may help decision makers better understand how climate change is impacting both resources and people, and how protected-area managers might best adapt to these changes. Fostering continued use of protected areas, where there is an explicit expectation of sustainable management, could provide examples of sustainable management for application beyond protected-area boundaries.

\section{Speculations about improved communication structures}

Participants felt strongly that Park staff should incorporate their observations into planning efforts, but did not offer suggestions about how this could be accomplished. Their silence on this issue may stem from the newness of the question or distrust that their observations will be valued. One option for improved communication would be to encourage increased use of online community observation networks, such as the Local Environmental Observers Network, where local communities can share observations via a collective website (http://www.anthc.org/ chs/ces/climate/leo/). This could serve as a resource for community members, Park staff, and Park visitors to upload and track changes observed in the Denali region.

\section{CONCLUSIONS}

Climate change is perhaps the largest system challenge that humanity has ever faced; cumulative human actions are changing every place in ways that are difficult to predict. Our institutions and existing funding streams are set up to favor bureaucratic decision making informed by expert opinion (Robbins 2004). The scientific process can demonstrate that climate change is happening and project how it will occur, but fine-scale information about impacts and adaptations will require local knowledge (Hulme 2010). This project demonstrates that different types of long-term local residents have different observations than Park staff and scientists based on their experience with and use of natural resources. This suggests the need to increase multistakeholder participation in climate adaptation planning so that decision makers can better understand change and design effective adaptation strategies.

This project demonstrates the value of fostering interaction between residents and protected areas. These interactions lead to novel observations, help to understand connections between ecological and social variables, and contribute memory, diversity, redundancy, and information about feedbacks. Protected areas face an onslaught of challenges: human actions impact all places regardless of their status (Steffen et al. 2007), existing reserve selection methods may not match with new dynamic realities (Araújo et al. 2004), and protected areas are often not large enough to encompass the long-term and large-scale dynamics of ecosystems (Bengtsson et al. 2003). Protected areas could take a leadership role in advancing new models of sustainability by allowing for controlled use of protected areas, with the expectation of sustainable management.

\section{Responses to this article can be read online at: http://www.ecologyandsociety.org/issues/responses. php/6906}

\section{Acknowledgments:}

Thank you to all the project participants for sharing their valuable observations, each of the project communities who graciously hosted the project team, and Beverly Gregory who helped us connect to community members in Nikolai. Dr Amy Lovecraft provided a valuable review of this paper. Thanks also to the anonymous reviewers whose suggestions improved the paper. This project was partially funded by the National Park Service and the Alaska EPSCOR program.

\section{LITERATURE CITED}

Adger, W. N., N. W. Arnell, and E. L. Tompkins. 2005. Successful adaptation to climate change across scales. Global Environmental Change 15:77-86. http://dx.doi.org/10.1016/j.gloenvcha.2004.12.005

Agrawal, A. 1995. Dismantling the divide between indigenous and scientific knowledge. Development and Change 26:413-439. http://dx.doi.org/10.1111/j.1467-7660.1995.tb00560.x

Alaska Department of Fish and Game (ADFG). 2013. Community subsistence information system. ADFG, Juneau, Alaska, USA. [online] URL: http://www.adfg.alaska.gov/sb/ CSIS/

Araújo, M. B., M. Cabeza, W. Thuiller, L. Hannah, and P. H. Williams. 2004. Would climate change drive species out of reserves? An assessment of existing reserve-selection methods. Global Change Biology 10:1618-1626. http://dx.doi.org/10.1111/ j.1365-2486.2004.00828.x

Beall, A., and L. Zeoli. 2008. Participatory modeling of endangered wildlife systems: simulating the sage-grouse and land use in Central Washington. Ecological Economics 68:24-33. http:// dx.doi.org/10.1016/j.ecolecon.2008.08.019

Bengtsson, J., P. Angelstam, T. Elmqvist, U. Emanuelsson, C. Folke, M. Ihse, F. Moberg, and M. Nystrom. 2003. Reserves, resilience and dynamic landscapes. Ambio 32:389-396.

Benson, M. H., and A. S. Garmestani. 2011. Can we manage for resilience? The integration of resilience thinking into natural resource management in the United States. Environmental Management 48:392-399. http://dx.doi.org/10.1007/s00267-011-9693-5 
Berkes, F., and D. Jolly. 2001. Adapting to climate change: socialecological resilience in a Canadian Western Arctic community. Conservation Ecology 5(2): 18. [online] URL: http://www. ecologyandsociety.org/vol5/iss2/art18/

Berkes, F., J. Colding, and C. Folke. 2000. Rediscovery of traditional ecological knowledge as adaptive management. Ecological Applications 10:1251-1262. http://dx.doi.org/10.1890/1051-0761 (2000)010[1251:ROTEKA]2.0.CO;2

Berkes, F., G. Kofinas, and F. S. Chapin III. 2009. Conservation, community, and livelihoods: sustaining, renewing, and adapting cultural connections to the land. Pages 129-147 in F. S. Chapin III, G. P. Kofinas, and C. Folke, editors. Principles of ecosystem stewardship resilience-based natural resource management in a changing world. Springer, New York, New York, USA. http://dx. doi.org/10.1007/978-0-387-73033-2_6

Byg, A., and J. Salick. 2009. Local perspectives on a global phenomenon-climate change in Eastern Tibetan villages. Global Environmental Change 19:156-166. http://dx.doi.org/10.1016/j. gloenvcha.2009.01.010

Caughley, G., and A. Gunn. 1996. Conservation biology in theory and practice. Blackwell Science, Cambridge, Massachusetts, USA.

Chapin, F. S. III, G. P. Kofinas, and C. Folke, editors. 2009. Principles of ecosystem stewardship resilience-based natural resource management in a changing world. Springer, New York, New York, USA.

Collins, R. 2004. Dichinanek' Hwt'ana. National Park Service, McGrath, Alaska, USA.

Council on Environmental Quality (CEQ). 2011. Federal agency climate change planning: implementing instructions: instructions for implementing climate change adaptation planning in accordance with Executive Order 13514. CEQ, Washington, D.C., USA.

Denzin, N., and Y. Lincoln. 2005. The SAGE handbook of qualitative research. Sage, Thousand Oaks, California, USA.

Dowie, M. 2009. Conservation refugees: the hundred-year conflict between global conservation and native peoples. MIT Press, Cambridge, Massachusetts, USA.

Folke, C. 2006. Resilience: the emergence of a perspective for social-ecological systems analyses. Global Environmental Change 16:253-267. http://dx.doi.org/10.1016/j.gloenvcha.2006.04.002

Gearheard S., M. Pocernich, R. Steward, J. Sanguya, and H. Huntington. 2010. Linking Inuit knowledge and meteorological station observations to understand changing wind patterns at Clyde River, Nunavut. Climatic Change 100:267-294. http://dx. doi.org/10.1007/s10584-009-9587-1

Government of USA. 1980. Alaska National Interest Lands Conservation Act. Public Law 96-487. 94 STAT. 2371. Washington, DC, USA.

Hagerman, S., H. Dowlatabadi, K. M. A. Chan, and T. Satterfield. 2010. Integrative propositions for adapting conservation policy to the impacts of climate change. Global Environmental Change 20:351-362. http://dx.doi.org/10.1016/j.gloenvcha.2009.11.002
Heller, N. E., and E. S. Zavaleta. 2009. Biodiversity management in the face of climate change: a review of 22 years of recommendations. Biological Conservation 142:14-32. http://dx. doi.org/10.1016/j.biocon.2008.10.006

Hulme, M. 2010. Problems with making and governing global kinds of knowledge. Global Environmental Change 20:558-564. http://dx.doi.org/10.1016/j.gloenvcha.2010.07.005

Jantarasami, L. C., J. J. Lawler, and C. W. Thomas. 2010. Institutional barriers to climate change adaptation in US National Parks and Forests. Ecology and Society 15(4): 33. [online] URL: http://www.ecologyandsociety.org/vol15/iss4/ $\underline{\operatorname{art} 331}$

Krupnik, I., and D. Jolly. 2002. The earth is faster now: indigenous observations of Arctic environment change. Arctic Research Consortium of the United States, Fairbanks, Alaska, USA.

Low, B., S. R. Sundaresan, I. R. Fischhoff, and D. I. Rubenstein. 2009. Partnering with local communities to identify conservation priorities for endangered Grevy's zebra. Biological Conservation 142:1548-1555. http://dx.doi.org/10.1016/j.biocon.2009.02.003

Moerlein, K. J., and C. Carothers. 2012. Total environment of change: impacts of climate change and social transitions on subsistence fisheries in Northwest Alaska. Ecology and Society 17(1): 10. http://dx.doi.org/10.5751/ES-04543-170110

National Park Service (NPS). 2010a. National Park Service climate change response strategy. Department of the Interior, Washington, D.C., USA.

National Park Service (NPS). 2010b. Alaska region climate change response strategy. Department of the Interior, Washington, D.C., USA.

National Park Service (NPS). 2012. Climate action plan: 2012-2014. National Park Service Climate Change Response Program Office. Department of the Interior, Washington, D.C., USA.

Ogden, A. E., and J. L. Innes. 2009. Application of structured decision making to an assessment of climate change vulnerabilities and adaptation options for sustainable forest management. Ecology and Society 14(1): 11. [online] URL: $\underline{\text { http:// }}$ www.ecologyandsociety.org/vol14/iss1/art11/

Peterson, D., C. Millar, L. Joyce, M. Furniss, J. Halofsky, R. Neilson, and T. Morelli. 2011. Responding to climate change in national forests: a guidebook for developing adaptation options. General Technical Report PNW-GTR-855. U.S. Forest Service, Pacific Northwest Research Station, Portland, Oregon, USA.

Robbins, P. 2004. Political ecology: a critical introduction. Blackwell, Malden, Massachusetts, USA.

Roland, C. A., J. H. Schmidt, and E. F. Nicklen. 2013. Landscapescale patterns in tree occupancy and abundance in subarctic Alaska. Ecological Monographs 83:19-48. http://dx.doi. org/10.1890/11-2136.1

Serreze, M. C., J. E. Walsh, F. S. Chapin III, T. Osterkamp, M. Dyurgerov, V. Romanovsky, W. C. Oechel, J. Morison, T. Zhang, and R. G. Barry. 2000. Observational evidence of recent change 
in the northern high-latitude environment. Climatic Change 46:159-207. http://dx.doi.org/10.1023/A:1005504031923

Shafer, C. L. 2012. Chronology of awareness about US National Park external threats. Environmental Management 50:1098-1110. http://dx.doi.org/10.1007/s00267-012-9946-y

State of Alaska. 2013. Community database online. Department of Commerce, Community, and Economic Development, Juneau, Alaska, USA. [online] URL: http://commerce.alaska.gov/cra/ DCRAExternal

Steffen, W., P. J. Crutzen, and J. R. McNeill. 2007. The anthropocene: Are humans now overwhelming the great forces of nature. Ambio 36:614-621. http://dx.doi.org/10.1579/0044-7447 (2007)36[614:TAAHNO]2.0.CO;2

Thomas, C. D., A. Cameron, R. E. Green, M. Bakkenes, L. J. Beaumont, Y. C. Collingham, B. F. N. Erasmus, M. F. de Siqueira, A. Grainger, L. Hannah, L. Hughes, B. Huntley, A. S. van Jaarsveld, G. F. Midgley, L. Miles, M. A. Ortega-Huerta, A. T. Peterson, O. L. Phillips, and S. E. Williams. 2004. Extinction risk from climate change. Nature 427:145-148. http://dx.doi. org/10.1038/nature02121

Tompkins, E. L., R. Few, and K. Brown. 2008. Scenario-based stakeholder engagement: incorporating stakeholders preferences into coastal planning for climate change. Journal of Environmental Management 88:1580-1592. http://dx.doi.org/10.1016/j. jenvman.2007.07.025

Treby, E. J., and M. J. Clark. 2004. Refining a practical approach to participatory decision making: an example from coastal zone management. Coastal Management 32:353-372. http://dx.doi. org/10.1080/08920750490487197

Turner, B. L., II, R. E. Kasperson, P. A. Matson, J. J. McCarthy, R. W. Corell, L. Christensen, N. Eckley, J. X. Kasperson, A. Luers, M. L. Martello, C. Polsky, A. Pulsipher, and A. Schiller. 2003. A framework for vulnerability analysis in sustainability science. Proceedings of the National Academy of Sciences of the United States of America 100:8074-8079. http://dx.doi.org/10.1073/ pnas. 1231335100

UNESCO World Heritage Centre. 2007. Case studies on climate change and world heritage. UNESCO World Heritage Centre, Paris, France.

Vogel, C., S. C. Moser, R. E. Kasperson, and G. D. Dabelko. 2007. Linking vulnerability, adaptation, and resilience science to practice: pathways, players, and partnerships. Global Environmental Change 17:349-364. http://dx.doi.org/10.1016/j. gloenvcha.2007.05.002

Weber, E. 2010. What shapes perceptions of climate change? Wiley Interdisciplinary Reviews: Climate Change 1:332-342. 
Appendix 1. Interview participants and associated characteristics.

\begin{tabular}{|c|c|c|c|c|}
\hline Category & Specific Role & Community & Residency & Years in Area \\
\hline Bus Driver & & McKinley Village & $\begin{array}{l}\text { Seasonal } \\
\text { Resident }\end{array}$ & 17 \\
\hline Bus Driver & & McKinley Village & $\begin{array}{l}\text { Seasonal } \\
\text { Resident }\end{array}$ & 24 \\
\hline Bus Driver & & McKinley Village & $\begin{array}{l}\text { Seasonal } \\
\text { Resident }\end{array}$ & 17 \\
\hline Bus Driver & & McKinley Village & $\begin{array}{l}\text { Seasonal } \\
\text { Resident }\end{array}$ & 37 \\
\hline Bus Driver & & McKinley Village & Resident & 36 \\
\hline Bus Driver & & McKinley Village & Resident & 33 \\
\hline Bus Driver & & McKinley Village & Resident & 35 \\
\hline Bus Driver & & Other (Fairbanks) & Seasonal Visitor & 32 \\
\hline Business Owner & Artist & Cantwell & Resident & 28 \\
\hline Business Owner & Artist & McKinley Village & Resident & 65 \\
\hline Business Owner & Artist & McKinley Village & Resident & 44 \\
\hline Business Owner & Guide & Cantwell & Resident & 53 \\
\hline Business Owner & Guide & Talkeetna & Resident & 43 \\
\hline Business Owner & Local agency & Cantwell & Resident & 52 \\
\hline Business Owner & Local agency & Talkeetna & Resident & 39 \\
\hline Business Owner & Miner & Talkeetna & Resident & 51 \\
\hline Business Owner & $\begin{array}{l}\text { Multiple } \\
\text { Businesses }\end{array}$ & McKinley Village & Resident & 49 \\
\hline Business Owner & $\begin{array}{l}\text { Multiple } \\
\text { Businesses } \\
\end{array}$ & Talkeetna & Resident & 34 \\
\hline Business Owner & Pilot & McKinley Village & $\begin{array}{l}\text { Seasonal } \\
\text { Resident }\end{array}$ & 27 \\
\hline Business Owner & Pilot & McKinley Village & Resident & 31 \\
\hline Business Owner & Pilot & Other (Fairbanks) & Seasonal Visitor & 33 \\
\hline Business Owner & Pilot & Talkeetna & Resident & 36 \\
\hline Business Owner & Tourism & Cantwell & Resident & 43 \\
\hline Business Owner & Tourism & Healy & Resident & 51 \\
\hline Business Owner & Tourism & McKinley Village & Resident & 46 \\
\hline Business Owner & Tourism & McKinley Village & Resident & 54 \\
\hline $\begin{array}{l}\text { NPS and/or } \\
\text { Scientist } \\
\end{array}$ & NPS Staff & McKinley Village & Resident & 34 \\
\hline $\begin{array}{l}\text { NPS and/or } \\
\text { Scientist } \\
\end{array}$ & NPS Staff & McKinley Village & Resident & 46 \\
\hline $\begin{array}{l}\text { NPS and/or } \\
\text { Scientist }\end{array}$ & NPS Staff & McKinley Village & Resident & 33 \\
\hline $\begin{array}{l}\text { NPS and/or } \\
\text { Scientist }\end{array}$ & NPS Staff & McKinley Village & Resident & 34 \\
\hline $\begin{array}{l}\text { NPS and/or } \\
\text { Scientist }\end{array}$ & NPS Staff & McKinley Village & Resident & 21 \\
\hline $\begin{array}{l}\text { NPS and/or } \\
\text { Scientist }\end{array}$ & NPS Staff & McKinley Village & Resident & 37 \\
\hline $\begin{array}{l}\text { NPS and/or } \\
\text { Scientist }\end{array}$ & NPS Staff & McKinley Village & Resident & 19 \\
\hline $\begin{array}{l}\text { NPS and/or } \\
\text { Scientist }\end{array}$ & NPS Staff & McKinley Village & Resident & 18 \\
\hline $\begin{array}{l}\text { NPS and/or } \\
\text { Scientist }\end{array}$ & NPS Staff & $\begin{array}{l}\text { Other } \\
\text { (Anchorage) }\end{array}$ & Seasonal Visitor & 37 \\
\hline
\end{tabular}


Appendix 1. Interview participants and associated characteristics

\begin{tabular}{|c|c|c|c|c|}
\hline Category & Specific Role & Community & Residency & Years in Area \\
\hline $\begin{array}{l}\text { NPS and/or } \\
\text { Scientist }\end{array}$ & NPS Staff & Talkeetna & Resident & 33 \\
\hline $\begin{array}{l}\text { NPS and/or } \\
\text { Scientist }\end{array}$ & Scientist & $\begin{array}{l}\text { Other } \\
\text { (Anchorage) }\end{array}$ & Seasonal Visitor & 36 \\
\hline $\begin{array}{l}\text { NPS and/or } \\
\text { Scientist }\end{array}$ & Scientist & Other (Fairbanks) & Seasonal Visitor & 59 \\
\hline $\begin{array}{l}\text { NPS and/or } \\
\text { Scientist }\end{array}$ & Scientist & McKinley Village & Resident & 24 \\
\hline $\begin{array}{l}\text { NPS and/or } \\
\text { Scientist }\end{array}$ & Scientist & McKinley Village & Resident & 25 \\
\hline $\begin{array}{l}\text { NPS and/or } \\
\text { Scientist }\end{array}$ & Scientist & $\begin{array}{l}\text { Other } \\
\text { (Anchorage) }\end{array}$ & Seasonal Visitor & 28 \\
\hline $\begin{array}{l}\text { NPS and/or } \\
\text { Scientist }\end{array}$ & Scientist & Other (Fairbanks) & Seasonal Visitor & 25 \\
\hline $\begin{array}{l}\text { NPS and/or } \\
\text { Scientist }\end{array}$ & Scientist & Other (Fairbanks) & Seasonal Visitor & 28 \\
\hline $\begin{array}{l}\text { NPS and/or } \\
\text { Scientist }\end{array}$ & Scientist & Other (Fairbanks) & Seasonal Visitor & 41 \\
\hline Subsistence & & Cantwell & Resident & 51 \\
\hline Subsistence & & Cantwell & Resident & 56 \\
\hline Subsistence & & Cantwell & Resident & 50 \\
\hline Subsistence & & Cantwell & Resident & 61 \\
\hline Subsistence & & Cantwell & Resident & 63 \\
\hline Subsistence & & Cantwell & Resident & 51 \\
\hline Subsistence & & Cantwell & Resident & 73 \\
\hline Subsistence & & Cantwell & Resident & 32 \\
\hline Subsistence & & Cantwell & Resident & 37 \\
\hline Subsistence & & Cantwell & Resident & 50 \\
\hline Subsistence & & Healy & Resident & 49 \\
\hline Subsistence & & Lake Minchumina & Resident & 9 \\
\hline Subsistence & & Lake Minchumina & Resident & 41 \\
\hline Subsistence & & Lake Minchumina & Resident & 36 \\
\hline Subsistence & & Lake Minchumina & Seasonal Visitor & 36 \\
\hline Subsistence & & Lake Minchumina & Seasonal Visitor & 36 \\
\hline Subsistence & & Lake Minchumina & Resident & 37 \\
\hline Subsistence & & Lake Minchumina & Resident & 10 \\
\hline Subsistence & & Lake Minchumina & Resident & 54 \\
\hline Subsistence & & Lake Minchumina & Resident & 54 \\
\hline Subsistence & & Nikolai & Resident & 65 \\
\hline Subsistence & & Nikolai & Resident & 86 \\
\hline Subsistence & & Nikolai & Resident & 33 \\
\hline Subsistence & & Nikolai & Resident & 65 \\
\hline Subsistence & & Nikolai & Resident & 67 \\
\hline Subsistence & & Nikolai & Resident & 65 \\
\hline Subsistence & & Nikolai & Resident & 89 \\
\hline
\end{tabular}


Appendix 1. Interview participants and associated characteristics

\begin{tabular}{|c|c|c|c|c|}
\hline Category & Specific Role & Community & Residency & Years in Area \\
\hline Subsistence & & Nikolai & Resident & 85 \\
\hline Subsistence & & Nikolai & Resident & 90 \\
\hline Subsistence & & Nikolai & Resident & 18 \\
\hline Subsistence & & Nikolai & Resident & 50 \\
\hline Subsistence & & Nikolai & Resident & 55 \\
\hline Subsistence & & Nikolai & Resident & 63 \\
\hline Subsistence & & Nikolai & Resident & 16 \\
\hline Subsistence & & Other (McGrath) & Seasonal Visitor & 43 \\
\hline Subsistence & & Talkeetna & Resident & 57 \\
\hline Subsistence & & Upper Kantishna & Seasonal Visitor & 24 \\
\hline Subsistence & & Upper Kantishna & Resident & 24 \\
\hline Subsistence & & Upper Kantishna & Resident & 24 \\
\hline
\end{tabular}


Appendix 2. Supplementary information on qualitative coding.

We created an introductory coding list based on our research questions and added codes as emergent themes arose (Bernard and Ryan 2010). Observations were coded as "climate change observations" if the interviewee labeled them as such or if they corresponded with scientific understanding of direct impacts of climate change. Observations that were not tied to climate change, were not direct impacts of climate change, had multiple drivers, or had an unknown connection, were coded as "other observations." The first author coded all of the transcripts. A first round of coding captured pre-existing themes of interest, while a second round made sure that all transcripts were coded for emergent themes. NVIVO generates quantitative reports as well as collecting the qualitative text referring to each theme. We categorized interviews by group (NPS staff, bus driver, subsistence and business owners) in order to compare and contrast observations, impacts, and adaptations.

\section{Literature Cited}

Bernard, H., and G. Ryan. 2010. Analyzing qualitative data: systematic approaches. Sage publications, Los Angeles, CA, USA. 


\begin{tabular}{|c|c|c|c|c|c|c|c|}
\hline & $\begin{array}{c}\text { Bus Driver } \\
n=8\end{array}$ & $\begin{array}{c}\text { Subsistence } \\
\text { Participant } \\
n=39\end{array}$ & $\begin{array}{c}\text { Business } \\
\text { owners } \\
\mathrm{n}=18\end{array}$ & $\begin{array}{c}\text { NPS Staff or } \\
\text { Scientist } \\
n=18\end{array}$ & $\begin{array}{l}\text { TOTAL } \\
n=83\end{array}$ & Example Quote & Scientific Literature \\
\hline Hydrology & $88 \%$ & $87 \%$ & $94 \%$ & $83 \%$ & $91 \%$ & & \\
\hline Drying ponds & $38 \%$ & $51 \%$ & $56 \%$ & $33 \%$ & $49 \%$ & $\begin{array}{l}\text { The lakes have all gotten smaller. A lot of the smaller ponds have just grown in or } \\
\text { muskeg bogs now. }\end{array}$ & Riordan 2006; Yoshikawa and Hinzman 200 \\
\hline Less snow & $25 \%$ & $46 \%$ & $67 \%$ & $39 \%$ & $49 \%$ & $\begin{array}{l}\text { We don't get the amount of snow that we used to get so I kind of that so it's like } \\
\text { you are not in the same place as you were when you were a kid. }\end{array}$ & \\
\hline Thawing permafrost & $25 \%$ & $49 \%$ & $33 \%$ & $22 \%$ & $39 \%$ & $\begin{array}{l}\text { Melting permafrost is slumping under sections of trail, requiring strenuous travel } \\
\text { or rerouting of trail }\end{array}$ & $\begin{array}{l}\text { Serreze et al. 2000; Osterkamp and Romanovsky } \\
1999 ; \text { Osterkamp, 2003; Clow and Urban, 2002; } \\
\text { Romanovsky yt a l, 2002 }\end{array}$ \\
\hline Retreating glaciers & $63 \%$ & $0 \%$ & $39 \%$ & $28 \%$ & $22 \%$ & $\begin{array}{l}\text { Polycrome glaciers I've heard are half the size. I don't know to me visually they } \\
\text { are practicaly gone. }\end{array}$ & $\begin{array}{l}\text { Serreze et al. 2000; Arendt et al, 2002; Dyurgerov } \\
\text { and Meler 1997 }\end{array}$ \\
\hline Later freeze-up of rivers & $0 \%$ & $28 \%$ & $17 \%$ & $6 \%$ & $19 \%$ & $\begin{array}{l}\text { Rivers freeze } 1-3 \text { weeks late, delaying departure in the most important time to } \\
\text { start trapping. }\end{array}$ & Magnuson et al. 2000; ; Ruhland et al. 2003 \\
\hline Lowered river levels & $0 \%$ & $31 \%$ & $11 \%$ & $6 \%$ & $19 \%$ & $\begin{array}{l}\text { But wh haven't had the rivers at flood stage now, well it's been a long time. I just } \\
\text { see less water. }\end{array}$ & Bolton et al. 2000 \\
\hline Gentler river break-up & $0 \%$ & $21 \%$ & $0 \%$ & $17 \%$ & $14 \%$ & $\begin{array}{l}\text { But one effect we've noticed is the river breakups. They aren't as violent as they } \\
\text { used to be. }\end{array}$ & \\
\hline Later snowfall & $13 \%$ & $10 \%$ & $17 \%$ & $17 \%$ & $14 \%$ & $\begin{array}{l}\text { Well beginning of September we've have some snow come through, you know, out } \\
\text { in the vallys, and we don't have that anymore. It's pretty well gone. So we don't } \\
\text { start gettling snow till towards the end of September }\end{array}$ & \\
\hline Increased erosion & $13 \%$ & $5 \%$ & $11 \%$ & $11 \%$ & $9 \%$ & $\begin{array}{l}\text { In the last few years I think we have seen more mud sildes in the canyon between } \\
\text { Igloo and Tatter Creek. They have had to close the road down because of them. }\end{array}$ & \\
\hline $\begin{array}{l}\text { Decrease in summer } \\
\text { snow patches }\end{array}$ & $38 \%$ & $0 \%$ & $22 \%$ & $0 \%$ & $9 \%$ & $\begin{array}{l}\text { Usually in mid-Sept there were still a few little patches although they may have } \\
\text { been dirty, but for at teasst } 10 \text { years they never melted and now every year they } \\
\text { are gone, usually by mid-August or so. }\end{array}$ & Stone et al. 2002 \\
\hline $\begin{array}{l}\text { Increased variation in } \\
\text { snowfall }\end{array}$ & $13 \%$ & $8 \%$ & $6 \%$ & $6 \%$ & $8 \%$ & $\begin{array}{l}\text { You know it is different every year. This year we had a lot of snow and it is varied } \\
\text { each year. }\end{array}$ & \\
\hline Chanelization of rivers & $0 \%$ & $10 \%$ & $6 \%$ & $0 \%$ & $6 \%$ & $\begin{array}{l}\text { In our trapping area, river channels are stablllzing, digging their. channels down } \\
\text { deeper while sard bars are getting overgrown. }\end{array}$ & \\
\hline $\begin{array}{ll}\text { Vegetation } \\
\text { Vetion }\end{array}$ & $100 \%$ & $\overline{74 \%}$ & 94\% & $94 \%$ & $89 \%$ & & \\
\hline Faster growth & $63 \%$ & $38 \%$ & $83 \%$ & $67 \%$ & $59 \%$ & $\begin{array}{l}\text { The vegetation is growing a lot faster and there are trees where they weren't } \\
\text { before. They seem to be growing a lot faster. }\end{array}$ & 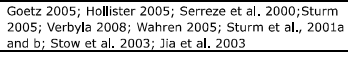 \\
\hline Treeline moving upwards & $100 \%$ & $10 \%$ & $50 \%$ & $61 \%$ & $40 \%$ & $\begin{array}{l}\text { It is so much more shrubby and I know trees are growing in passes that never } \\
\text { had trees like Thoroughffare and Sable. }\end{array}$ & $\begin{array}{l}\text { Potter 2004; Stueve 2011; Bigelow 2003; Chapin 1995; } \\
\text { Chapin 1996; Danby 2007; Hobbie \& Chapin } 1998 ; \\
\text { Serreze et al. 2000; Soja 2007; Loyd and Fastie 2002 }\end{array}$ \\
\hline Tundra drying & $13 \%$ & $18 \%$ & $17 \%$ & $17 \%$ & $17 \%$ & $\begin{array}{l}\text { Last year I was hiking up here on Reindeer and you know it was the first time ever } \\
\text { that I've felt this way but I was hiking up on Reindeer and it's all "ried out. I was } \\
\text { walking raound and this is all prettrty thick peat. I said to myself," "This thing could } \\
\text { burn. We could have a tundra firel" }\end{array}$ & Verbyla 2008 \\
\hline Gardening easier & $0 \%$ & $21 \%$ & $11 \%$ & $11 \%$ & $15 \%$ & $\begin{array}{l}\text { It's got good points: it's easier to garden, longer growing season, plants are } \\
\text { overwintering that never overwintered before. }\end{array}$ & \\
\hline Shifts in phenology & $13 \%$ & $5 \%$ & $11 \%$ & $17 \%$ & $10 \%$ & $\begin{array}{l}\text { We have only been studying the phenology since } 2005 \text { and it has been } \\
\text { dramatically variable, like } 2-3 \text { weeks difference in green up which is large given } \\
\text { our growing season. }\end{array}$ & \\
\hline Rising firn line & $13 \%$ & $0 \%$ & $28 \%$ & $6 \%$ & $9 \%$ & $\begin{array}{l}\text { Firn lines. when I first started fying they were at like } 6-7,000 \mathrm{ft} \text { and it would melt } \\
\text { a little in parts of the summer but you could count on the peaks about } 8,000 \text { to to } \\
\text { always be frozen and kept in snow and now that line is to to at least } 10,000 \mathrm{ft} \text {. }\end{array}$ & \\
\hline Weather & $100 \%$ & $95 \%$ & $94 \%$ & $56 \%$ & $90 \%$ & & \\
\hline Temperature increase & $75 \%$ & $79 \%$ & $78 \%$ & $33 \%$ & $71 \%$ & $\begin{array}{l}\text { Yeah, I think so because there used to be cold cold winters. It is hardly cold } \\
\text { anymore, I guess the climate has changed a lot. }\end{array}$ & $\begin{array}{l}\text { Serreze et al. } 2000 \text {, Chapman and Walsh 1993, } \\
\text { Overpeck et al. } 1997\end{array}$ \\
\hline More frequent fire & $25 \%$ & $38 \%$ & $33 \%$ & $28 \%$ & $35 \%$ & We are also getting frequent fires and that is not normal. & Kasischke 2006, Soja 2007 \\
\hline Longer summers & $0 \%$ & $23 \%$ & $56 \%$ & $11 \%$ & $26 \%$ & $\begin{array}{l}\text { In the fall we had our first freezing morning today and usually after August 15th } \\
\text { we't get a kiling frost but that doesn't happen. Obviously the frost-free season is } \\
\text { elongating. }\end{array}$ & \\
\hline More wind & $0 \%$ & $26 \%$ & $33 \%$ & $0 \%$ & $19 \%$ & We had more wind, we had heavier snows, and the temperatures were colder. & \\
\hline Increase in winter rain & $25 \%$ & $18 \%$ & $17 \%$ & $17 \%$ & $19 \%$ & $\begin{array}{l}\text { One of the biggestc hanges we have seen here, which remains to be seen as ow } \\
\text { it is effecting the wildifife, is the winters here are a little shorter and we get winter } \\
\text { rains now which is a pretty rare occurrence at this latitude. }\end{array}$ & \\
\hline $\begin{array}{l}\text { More extreme } \\
\text { temperatures }\end{array}$ & $0 \%$ & $21 \%$ & $17 \%$ & $11 \%$ & $16 \%$ & $\begin{array}{l}\text { Now it will go from an extreme cold to an extreme warm. We are getting a lot } \\
\text { more spikes. }\end{array}$ & \\
\hline More thunderstorms & $25 \%$ & $5 \%$ & $33 \%$ & $6 \%$ & $14 \%$ & $\begin{array}{l}\text { We never used to have lightening storms before. When we started to get them } \\
\text { they were with rain but now it seems like we are getting lightning without rain. }\end{array}$ & \\
\hline
\end{tabular}


Appendix 4. Nonclimate related changes observed by interview participants.

\begin{tabular}{|c|c|c|c|c|c|c|}
\hline & $\begin{array}{c}\text { Bus Driver } \\
\mathrm{n}=8\end{array}$ & $\begin{array}{c}\text { Subsistence } \\
\text { Participant } \\
\mathrm{n}=39\end{array}$ & $\begin{array}{c}\text { Business } \\
\text { Owners } \\
n=18\end{array}$ & $\begin{array}{l}\text { NPS Staff } \\
\text { or Scientist } \\
\mathrm{n}=18\end{array}$ & $\begin{array}{c}\text { TOTAL } \\
\mathrm{n}=83\end{array}$ & Example Quote \\
\hline Air quality decline & $0 \%$ & $3 \%$ & $17 \%$ & $0 \%$ & $5 \%$ & $\begin{array}{l}\text { There aren't as clear of skies. I don't remember what year it was } \\
\text { that we first noticed but we were told it was arctic haze. It may } \\
\text { have been } 20 \text { years ago }\end{array}$ \\
\hline $\begin{array}{l}\text { Change in Park } \\
\text { management and } \\
\text { philosophy }\end{array}$ & $38 \%$ & $15 \%$ & $22 \%$ & $11 \%$ & $18 \%$ & $\begin{array}{l}\text { They have managers that come in and that are very skilled as } \\
\text { managers but they don't have the long term picture of what's } \\
\text { happening they just see, "Oh we need, this place is undeveloped. } \\
\text { There are not enough services. We need more." But they aren't } \\
\text { seeing the impact it's having on the overall experience. }\end{array}$ \\
\hline Changes in wildlife & $100 \%$ & $92 \%$ & $100 \%$ & $78 \%$ & $92 \%$ & $\begin{array}{l}\text { I think the habitat change is important to all the wildlife. Most } \\
\text { specifically I think it is effecting the caribou numbers. }\end{array}$ \\
\hline $\begin{array}{l}\text { Community changes } \\
\text { (outside Denali) }\end{array}$ & $38 \%$ & $51 \%$ & $28 \%$ & $33 \%$ & $41 \%$ & \\
\hline Less community cohesion & $0 \%$ & $13 \%$ & $11 \%$ & $6 \%$ & $10 \%$ & $\begin{array}{l}\text { It feels pretty split. In those days everyone did things together } \\
\text { and they used to have potlucks and picnics. }\end{array}$ \\
\hline $\begin{array}{r}\text { More people and traffic } \\
\text { outside the Park }\end{array}$ & $0 \%$ & $23 \%$ & $44 \%$ & $11 \%$ & $23 \%$ & $\begin{array}{l}\text { There has been so much change here. Before the highway, it was } \\
\text { different. The whole community was just based around the } \\
\text { railroad and the section house. }\end{array}$ \\
\hline $\begin{array}{r}\text { Loss of culture in next } \\
\text { generation }\end{array}$ & $0 \%$ & $36 \%$ & $6 \%$ & $0 \%$ & $18 \%$ & $\begin{array}{l}\text { There are few of the younger people who want to know our } \\
\text { culture. The young people hardly speak the language and it isn't } \\
\text { like it used to be. People are missing out. They might as well live } \\
\text { in town. }\end{array}$ \\
\hline $\begin{array}{l}\text { Impacts of earthquakes } \\
\text { and volcanos }\end{array}$ & $0 \%$ & $21 \%$ & $6 \%$ & $6 \%$ & $12 \%$ & $\begin{array}{l}\text { I think the } 1964 \text { earthquake must have lowered the land or } \\
\text { flooded it. The land had totally changed in the interim and it was } \\
\text { totally different than before. }\end{array}$ \\
\hline Increase in technology & $13 \%$ & $56 \%$ & $28 \%$ & $28 \%$ & $40 \%$ & $\begin{array}{l}\text { Yeah, that really changed when the snow mobile came. Changed } \\
\text { everything to vehicles for hunting. People were all over. You'd } \\
\text { probably notice it too. Easier way to hunt, they have lots of } \\
\text { money and lots of equipment. Long time ago we never had no } \\
\text { money. }\end{array}$ \\
\hline Local travel access & $0 \%$ & $15 \%$ & $6 \%$ & $0 \%$ & $8 \%$ & $\begin{array}{l}\text { I don't know if they, the Park Service, feels like they've shut us } \\
\text { out but they've restricted enough that we feel like we've been } \\
\text { shut out. }\end{array}$ \\
\hline Park experience & $100 \%$ & $13 \%$ & $72 \%$ & $72 \%$ & $47 \%$ & \\
\hline Change in quality & $38 \%$ & $0 \%$ & $17 \%$ & $11 \%$ & $10 \%$ & $\begin{array}{l}\text { There has been a huge increase in overflights, and this has been a } \\
\text { problem since the early } 1980 \text { 's. It changes the whole backcountry } \\
\text { experience. }\end{array}$ \\
\hline More people in Park & $25 \%$ & $5 \%$ & $33 \%$ & $61 \%$ & $25 \%$ & $\begin{array}{l}\text { You see many more hikers and backpackers out in the landscape } \\
\text { then we ever used to and in the } 1960 \text { 's early } 1970 \text { 's. }\end{array}$ \\
\hline $\begin{array}{r}\text { Pressure for increased Park } \\
\text { access }\end{array}$ & $88 \%$ & $5 \%$ & $56 \%$ & $44 \%$ & $33 \%$ & $\begin{array}{l}\text { I am so worried about the politics because of the way the tourist } \\
\text { industry dictates what happens here you know...they just want } \\
\text { more and more people in here. }\end{array}$ \\
\hline $\begin{array}{l}\text { Types of Park visitors (e.g., } \\
\text { less independent travellers) }\end{array}$ & $50 \%$ & $0 \%$ & $6 \%$ & $17 \%$ & $10 \%$ & $\begin{array}{l}\text { Oh definitely, most people would say more industrial tourism. It } \\
\text { used to be more independent tourists traveling on their own. }\end{array}$ \\
\hline
\end{tabular}


Appendix 5. Perceived impacts of observed changes by participant group (in percentages).

\begin{tabular}{|c|c|c|c|c|c|}
\hline & $\begin{array}{c}\text { Bus Driver } \\
n=8\end{array}$ & $\begin{array}{c}\text { Subsistence } \\
n=39\end{array}$ & $\begin{array}{c}\text { Business } \\
\text { Owner } \\
n=18\end{array}$ & $\begin{array}{l}\text { NPS Staff or } \\
\text { Scientist } \\
n=18\end{array}$ & $\begin{array}{l}\text { Total } \\
n=83\end{array}$ \\
\hline Restricted access & $13 \%$ & $54 \%$ & $44 \%$ & $33 \%$ & $43 \%$ \\
\hline Rivers (weather related) & $0 \%$ & $36 \%$ & $11 \%$ & $11 \%$ & $22 \%$ \\
\hline Snow Travel (weather related) & $13 \%$ & $26 \%$ & $0 \%$ & $0 \%$ & $13 \%$ \\
\hline Trails (policy and vegetation related) & $0 \%$ & $15 \%$ & $11 \%$ & $0 \%$ & $10 \%$ \\
\hline Air travel (policy related) & $0 \%$ & $3 \%$ & $11 \%$ & $6 \%$ & $5 \%$ \\
\hline Mountaineering (weather related) & $0 \%$ & $0 \%$ & $11 \%$ & $11 \%$ & $5 \%$ \\
\hline Roads (policy related) & $0 \%$ & $0 \%$ & $0 \%$ & $11 \%$ & $2 \%$ \\
\hline Change to subsistence resources & $0 \%$ & $74 \%$ & $61 \%$ & $33 \%$ & $55 \%$ \\
\hline Shift in distribution of animals & $0 \%$ & $49 \%$ & $44 \%$ & $17 \%$ & $36 \%$ \\
\hline Gardening extended & $0 \%$ & $21 \%$ & $11 \%$ & $11 \%$ & $14 \%$ \\
\hline Change in meat storage & $0 \%$ & $23 \%$ & $0 \%$ & $6 \%$ & $12 \%$ \\
\hline Decreased ability to locate game & $0 \%$ & $26 \%$ & $0 \%$ & $0 \%$ & $12 \%$ \\
\hline Fewer game to harvest & $0 \%$ & $23 \%$ & $0 \%$ & $6 \%$ & $12 \%$ \\
\hline Change in quality of game & $0 \%$ & $10 \%$ & $0 \%$ & $0 \%$ & $5 \%$ \\
\hline Challenge harvesting wood & $0 \%$ & $3 \%$ & $11 \%$ & $0 \%$ & $4 \%$ \\
\hline Decreased water quality & $0 \%$ & $3 \%$ & $6 \%$ & $0 \%$ & $2 \%$ \\
\hline Decrease in berry harvest & $0 \%$ & $3 \%$ & $0 \%$ & $0 \%$ & $1 \%$ \\
\hline Improved trapping for furbearers & $0 \%$ & $3 \%$ & $0 \%$ & $0 \%$ & $1 \%$ \\
\hline Social Impacts & $63 \%$ & $5 \%$ & $28 \%$ & $72 \%$ & $30 \%$ \\
\hline Infrastructure impacts & $13 \%$ & $0 \%$ & $17 \%$ & $17 \%$ & $8 \%$ \\
\hline Brush on roads (increased maintenance) & $13 \%$ & $5 \%$ & $0 \%$ & $17 \%$ & $7 \%$ \\
\hline Changes to monitoring plan & $13 \%$ & $0 \%$ & $0 \%$ & $22 \%$ & $6 \%$ \\
\hline Changes to climate change communication & $38 \%$ & $0 \%$ & $0 \%$ & $11 \%$ & $6 \%$ \\
\hline Longer tourism season & $0 \%$ & $0 \%$ & $11 \%$ & $11 \%$ & $5 \%$ \\
\hline Easier to heat & $13 \%$ & $0 \%$ & $11 \%$ & $0 \%$ & $4 \%$ \\
\hline Decrease in mental health & $0 \%$ & $0 \%$ & $11 \%$ & $0 \%$ & $2 \%$ \\
\hline Fire season is longer & $0 \%$ & $0 \%$ & $0 \%$ & $6 \%$ & $1 \%$ \\
\hline Changes to wildlife viewing opportunities & $75 \%$ & $5 \%$ & $50 \%$ & $33 \%$ & $28 \%$ \\
\hline
\end{tabular}

